\title{
HUBUNGAN ANTARA OVERWEIGHT DENGAN NYERI PUNGGUNG BAWAH DI RSUD KANJURUHAN KEPANJEN PERIODE JANUARI-DESEMBER TAHUN 2013
}

\author{
Nurhiqmah Aisyiah Fitriyani ${ }^{1}$, Febri EBS ${ }^{2}$, Desy Andari ${ }^{3}$
}

Fakultas Kedokteran Universitas Muhammadiyah Malang, J1. Bendungan Sutami No. 188-A, Kota Malang, 65145, Indonesia, 0341-552443 / 0341-551149

\begin{abstract}
ABSTRAK
HUBUNGAN ANTARA OVERWEIGHT DENGAN NYERI PUNGGUNG BAWAH DI RSUD KANJURUHAN KEPANJEN PERIODE JANUARI-DESEMBER TAHUN 2013. Latar Belakang: Nyeri punggung bawah merupakan suatu gangguan muskuloskeletal pada daerah punggung bawah yang banyak dikeluhkan penderita yang berkunjung ke dokter. Banyak faktor yang dapat memperberat resiko terjadinya nyeri punggung bawah, salah satunya adalah overweight. Tujuan Penelitian: Mengetahui hubungan, kuatnya pengaruh dan besarnya factor resiko antara overweight dengan nyeri punggung bawah di RSUD Kanjuruhan Kepanjen periode Januari-Desember tahun 2013. Metode Penelitian: Penelitian observasional analitik dengan pendekatan cross sectional, dengan besar sampel sebanyak 82 orang yaitu 41 penderita nyeri punggung bawah dan 41 orang lainnya penderita non nyeri punggung bawah. Analisis data dengan menggunakan statistik uji chi-square dengan á=0.05 dan uji korelasi koefisien kontingensi. Hasil Penelitian: Menunjukkan bahwa penderita dengan diagnosis nyeri punggung bawah yang datang ke RSUD Kanjuruhan Kepanjen memiliki indeks massa tubuh kategori overweight (30.5\%), sedangkan sampel yang overweight tapi non nyeri punggung bawah (13.4\%). Kesimpulan: Terdapat hubungan yang signifikan antara overweight dengan nyeri punggung bawah di RSUD Kanjuruhan Kepanjen periode Januari-Desember tahun 2013 ( $\mathrm{p}=0.002)$. Overweight memberikan pengaruh yang tidak begitu kuat (lemah) terhadap nyeri punggung bawah $(\mathrm{r}=0.325)$ dan seseorang yang overweight mempunyai resiko yang lebih besar untuk mengalami nyeri punggung bawah $(\mathrm{OR}=4.261)$.
\end{abstract}

Kata Kunci: Overweight, Nyeri punggung bawah

\section{ABSTRACT}

The correlation between overweight and Low Back Pain In Kanjuruhan Hospital of Kepanjen in the period January to December 2013. Background: Low back pain is a musculoskeletal disorders in the lower back area complained that many patients who visit the doctor. Many factors will increase the risk of low back pain, one of them is overweight. Objective: To find out the correlation, effect and risk factor between overweight and low back pain in Kanjuruban general hospital of Kepanjen in the period January to December 2013. Methods: This research use analytic observational which applies cross sectional approach, the retrieval of data by purposive sampling. It takes 82 patients at 41 low back pain patients and 41 other non-low back pain patients. This research also use chi-square method by $a=0.05$ and contingency coefficient correlation. Results: The results showed that patients with low back pain in Kanjuruban Kepanjen Hospital had body mass index of overweight category (30.5\%), while samples who overweight but did not suffer from low back pain at 13.4\%. Conclusion: There is a significant correlation between overweight and low back pain in Kanjuruhan Kepanjen Hospital in the period January to December 2013 (with a value of $p=0.002$ ). Effect of overweight is not so strong (weak) to low back pain $(r=0.325)$ and someone who is overweight have a greater risk of low back pain $(\mathrm{OR}=4.261)$.

Key word: Overweight, Low back pain

\section{PENDAHULUAN}

Nyeri punggung bawah sering dijumpai dalam praktek sehari-hari, terutama di negara-negara industri. Sekitar 80$90 \%$ pasien nyeri punggung bawah menyatakan bahwa mereka tidak melakukan usaha apapun untuk mengobati penyakitnya (Cooper, 2003). Di Amerika Serikat, keluhan nyeri punggung bawah ini menempati keluhan tersering urutan kedua setelah nyeri kepala (Bener et al, 2003). Di Indonesia, penelitian yang dilakukan oleh Community Oriented Program for Controle of Rheumatic Disease (COPORD) menunjukkan prevalensi nyeri punggung bawah 18,2\% pada laki-laki dan 13,6\% pada wanita (Rumiyati, 2009).

Penelitian yang dilakukan kelompok studi nyeri PERDOSSI pada 14 rumah sakit pendidikan di Indonesia, pada bulan Mei 2002 menunjukkan jumlah penderita nyeri sebanyak 4.456 orang ( $25 \%$ dari total kunjungan), dimana 1.598 orang $(35,86 \%)$ adalah penderita nyeri punggung bawah (Lubis I, 2003). 
Nyeri punggung bawah merupakan keluhan yang sering kita dengar dari orang usia lanjut, namun tidak menutup kemungkinan dialami oleh orang usia muda (Paliyama, 2003). Nyeri punggung bawah merupakan salah satu gangguan muskuloskeletal pada daerah punggung bawah yang disebabkan oleh aktivitas tubuh yang kurang baik (Maher, Salmond \& Pellino, 2002). Menurut Rachel (2005), low back pain adalah nyeri punggung bawah yang berasal dari tulang belakang, otot, saraf atau struktur lain pada daerah tersebut.

Beberapa faktor resiko yang berpotensi menyebabkan terjadinya nyeri punggung bawah antara lain usia, jenis kelamin, indeks massa tubuh, pekerjaan, merokok, angkat beban yang berat berulang-ulang, membungkuk, duduk lama, faktor psikologis (Sidharta, 2009).

Perubahan pola makan (pola konsumsi pangan) pada zaman sekarang baik di negara maju maupun negara berkembang termasuk Indonesia, khususnya di kota besar dan pada golongan sosial ekonomi tertentu, yaitu adanya kecenderungan untuk mengkonsumsi makanan dengan kalori berlebihan disertai dengan kurangnya aktivitas fisik sehingga insiden overweight dan obesitas juga cenderung makin meningkat (Siswono, 2004). Data yang ada saat ini sudah menunjukkan terjadinya pertambahan jumlah penduduk dengan overweight, khususnya di kota-kota besar (Sugondo, 2007). Di Indonesia, berdasarkan hasil Riset Kesehatan Dasar Nasional 2007 prevalensi obesitas umum secara nasional adalah 19,1\% (8,8\% overweight dan 10,3\% obesitas). Prevalensi untuk wilayah Jawa Timur 9,1\% overweight dan $11,3 \%$ obesitas. Hal tersebut dapat mengakibatkan masalah kesehatan yang serius karena obesitas dapat memacu kelainan kardiovaskuler, ginjal, metabolik dan neuromuskuler (WHO, 2006).

Besarnya resiko overweight terhadap nyeri punggung bawah telah dibuktikan di beberapa penelitian. Hendi Purnamasari (2009) mendapatkan seseorang yang overweight lebih beresiko 5 kali menderita nyeri punggung bawah dibandingkan dengan orang yang memiliki berat badan ideal dengan persentase 65,6\% dari 90 responden. Vismara L. (2010) menyimpulkan bahwa peningkatan insiden nyeri punggung bawah terjadi seiring dengan peningkatan indeks massa 3 tubuh. Hasil penelitian yang dilakukan Richard dan Weinstein (2001) menyimpulkan bahwa risiko nyeri punggung bawah meningkat pada seseorang yang overweight.

Ketika berat badan seseorang bertambah, akan terjadi peningkatan beban pada daerah lumbosakral. Area ini merupakan penyokong utama berat badan kita. Beban berlebih tersebut dapat menyebabkan kelainan postural dan kerusakan pada otot sehingga menghasilkan lesi kronik yang lama kelamaan akan merusak selubung myelin. Hal tersebut akan menghasilkan reaksi berlebihan pada saraf yang disebut hipersensitivitas. Hipersensitivitas pada daerah lumbosakral inilah yang biasa dikeluhkan sebagai nyeri punggung bawah (Lubis I, 2003).

Dari studi pendahuluan yang telah dilakukan di RSUD Kanjuruhan Kepanjen didapatkan adanya peningkatan jumlah total kunjungan pasien nyeri punggung bawah dari tahun ke tahun. Pada periode Januari-Desember tahun 2012 terdapat kasus nyeri punggung bawah sebanyak 1765 orang dengan kasus baru sebanyak 330 orang (18.7\%), sedangkan pada periode tahun 2013 terdapat kasus nyeri punggung bawah sebanyak 1950 orang dengan kasus baru 408 orang $(20.9 \%)$. Berdasarkan latar belakang tersebut, peneliti tertarik untuk melakukan penelitian tentang hubungan antara overweight dengan nyeri punggung bawah di RSUD Kanjuruhan Kepanjen periode Januari-Desember tahun 2013.

\section{METODE}

Rancangan penelitian yang digunakan dalam penelitian ini adalah analitik observasional dengan pendekatan cross sectional. Penelitian Penelitian akan dilaksanakan di Rekam Medik RSUD Kanjuruhan Kepanjen.

Populasi pada penelitian ini adalah pasien yang datang periksa ke poli saraf RSUD Kanjuruhan Kepanjen periode Januari-Desember 2013 berdasarkan data pada rekam medis. Adapun sampel yang digunakan pada penelitian ini adalah pasien yang datang periksa ke poli saraf RSUD Kanjuruhan Kepanjen periode Januari-Desember 2013 yang sesuai dengan kriteria inklusi. Kemudian disesuaikan dengan kriteria inklusi yaitu pasien dengan diagnosis NPB (Nyeri Punggung Bawah) berdasarkan data rekam medis periode Januari-Desember 2013 dan Sampel kontrol pasien yang non NPB berdasarkan data rekam medis periode Januari-Desember 2013. Sedangkan kriteria eksklusi pada penelitian ini adalah pasien yang memiliki riwayat trauma pada daerah lumbal, pasien yang memiliki riwayat penyakit infeksi misal infeksi bakteri tuberkulosis, pasien yang memiliki kelainan vertebra sejak lahir atau kongenital diantaranya spina bifida, kissing spine, dan Spondylisthesis, dan Pasien yang memiliki riwayat penyakit degenerasi seperti Osteoarthritis dan osteoporosis.

Teknik pengambilan sampel yang digunakan adalah dengan menggunakan teknik purposive sampling. Variabel bebas yang digunakan pada penelitian ini adalah overweight dan sebagai variabel terikat adalah nyeri punggung bawah. Overweight adalah suatu kondisi dimana perbandingan berat badan dan tinggi badan melebihi standar yang ditentukan. Cara sederhana untuk mengetahui status gizi orang dewasa, didapat dari perhitungan dengan rumus: $\mathrm{IMT}=\mathrm{BB}(\mathrm{Kg}) /$ $\mathrm{TB}^{2}(\mathrm{~m})$. Klasifikasi indeks massa tubuh menurut WHO yaitu normal 18,50-24,99 kg/m2, overweight $>25,00 \mathrm{~kg} / \mathrm{m} 2$, dan obesitas $>30 \mathrm{~kg} / \mathrm{m} 2$.

Nyeri punggung bawah adalah suatu gejala nyeri atau perasaan tidak enak di daerah tulang punggung bagian bawah. Data didapat dari diagnosis yang tercantum dalam rekam medis. Sampel kontrol diambil dari pasien yang non NPB seperti epilepsy, tension headache, neuropati, migrain, HNP, vertigo. Data didapat dari diagnosis yang tercantum dalam rekam medis. Pada penelitian ini digunakan data rekam medis pasien NPB periode Januari-Desember 2013 yang diambil dari RSUD Kanjuruhan Kepanjen sebagai data sekunder.

Kemudian Data diolah dan dianalisis secara komputerisasi dengan menggunakan alat bantu SPSS (Statistical Program and Service Solution). Data hasil penelitian disajikan dalam bentuk tabel. Hubungan antara variabel dependen dan independen Eksklusi Inklusi IMT Normal Analisis Data IMT > 25 Hasil Data rekam medis pasien 
yang datang ke poli saraf RSUD Kanjuruhan Kepanjen periode Januari-Desember 2013 NPB Non NPB IMT Normal IMT > 25 dianalisis bivariat. Uji hipotesis yang digunakan pada analisis bivariat ialah uji chi-square (X2). nyeri punggung bawah. Data diperoleh berdasarkan hasil observasi untuk mengetahui hubungan antara overweight dengan nyeri punggung bawah di RSUD Kanjuruhan Kepanjen.

\section{HASIL DAN PEMBAHASAN}

Penelitian dilakukan terhadap 82 sampel yaitu 41 penderita nyeri punggung bawah yang datang ke RSUD Kanjuruhan Kepanjen dan 41 orang lainnya penderita non

Tabel 1. Distribusi Frekuensi Karakteristik Sampel

\begin{tabular}{llcc}
\hline \multirow{2}{*}{ Variabel } & & Frekuensi & Persentase (\%) \\
& & & \\
\hline Jenis Kelamin & Laki-laki & 33 & 40,2 \\
& Perempuan & 49 & 59,8 \\
Usia & $<40$ tahun & 17 & 20,7 \\
& 40-55 tahun & 48 & 58,6 \\
IMT & $>55$ tahun & 17 & 20,7 \\
& Normal & 46 & 56,1 \\
NPB & Overweight & 36 & 43,9 \\
& Negatif & 41 & 50,0 \\
\hline
\end{tabular}

(Data Sekunder yang diolah, 2014)

Tabel 2. Tabulasi silang antara overweight dan nyeri punggung bawah

\begin{tabular}{lccccc}
\hline & & \multicolumn{2}{c}{ NPB } & \multirow{2}{*}{ Total } \\
\cline { 3 - 5 } & & & Negatif & Positif & \\
\hline IMT & Normal & Total & $30(36,6 \%)$ & $16(19,25 \%)$ & $46(56,1 \%)$ \\
& Overweight & Total & $11(13,4 \%)$ & $25(30,5 \%)$ & $36(43,9 \%)$ \\
\hline Total & & Total & $41(50,0 \%)$ & $41(50,0 \%)$ & $82(100 \%)$ \\
\hline
\end{tabular}

Chi square $=9.705$ dan signifikansi $(p)=0.002$

Tabel 3. Hasil Korelasi Koefisien Kontingensi overweight dan nyeri punggung bawah

\begin{tabular}{lll}
\hline $\begin{array}{l}\text { Hubungan } \\
\text { Variabel }\end{array}$ & Koef. Korelasi & p-value (sig) \\
\hline $\begin{array}{l}\text { Overweight dan } \\
\text { nyeri punggung } \\
\text { bawah }\end{array}$ & 0,325 & 0,002
\end{tabular}

Tabel 3. Hasil odd ratio antara overweight dan nyeri punggung bawah

\begin{tabular}{lcc}
\hline Hubungan Variabel & $\begin{array}{c}\text { Odd Ratio } \\
(\mathrm{OR})\end{array}$ & $\begin{array}{c}\text { 95\% Confidence } \\
\text { Interval }\end{array}$ \\
\hline $\begin{array}{l}\text { Overweight dan nyeri } \\
\text { punggung bawah }\end{array}$ & 4.261 & $1.676-10.836$
\end{tabular}


Berdasarkan tabel 1 dapat diketahui bahwa dari 41 sampel penderita nyeri punggung bawah, sampel terbanyak adalah yang berjenis kelamin perempuan berjumlah 25 orang $(61.0 \%)$, sedangkan yang berjenis kelamin lakilaki berjumlah 16 orang (39.0\%). Pada sampel yang berusia 40 55 tahun merupakan sampel terbanyak yang berjumlah 22 orang (53.7\%), sedangkan yang berusia $<40$ tahun berjumlah $(24.4 \%)$ dan yang berusia $>55$ tahun berjumlah 9 orang $(22.0 \%)$. Sampel yang memiliki indeks massa tubuh normal berjumlah 46 orang $(56.1 \%)$ dan yang memiliki indeks massa tubuh overweight berjumlah 36 orang (43.9\%). Sampel dengan diagnosis nyeri punggung bawah berjumlah 41 orang $(50.0 \%)$ dan yang non nyeri punggung bawah berjumlah 41 orang $(50.0 \%)$.

Pada hasil tabel tabulasi silang (crosstabs) di atas (tabel 2) dapat diketahui bahwa sampel yang non nyeri punggung bawah dengan IMT normal merupakan sampel terbanyak yaitu berjumlah 30 orang (36.6\%). Sampel yang menderita nyeri punggung bawah dengan IMT normal berjumlah 16 orang $(19.5 \%)$. Sampel yang menderita nyeri punggung bawah dengan IMT overweight berjumlah 25 orang (30.5\%), sedangkan sampel yang non nyeri punggung bawah dengan IMT overweight berjumlah 11 orang (13.4\%).

Berdasarkan hasil pengujian di atas menunjukkan nilai chi-Square sebesar 9.705 dengan nilai signifikansi (p) sebesar 0.002 yang lebih kecil dari alpha 0.05 , memiliki nilai korelasi koefisien kontingensi ( $\mathrm{r}$ ) sebesar 0.325 dan memiliki nilai OR sebesar 4.261. Sehingga dapat disimpulkan bahwa antara overweight dan nyeri punggung bawah di RSUD Kanjuruhan Kepanjen mempunyai hubungan yang signifikan (bermakna).

Penelitian ini dilakukan untuk menggambarkan dan mengetahui adanya hubungan antara overweight dengan nyeri punggung bawah di RSUD Kanjuruhan Kepanjen dengan menggunakan data sekunder dari rekam medis. Sampel yang digunakan dalam penelitian ini adalah penderita nyeri punggung bawah di RSUD Kanjuruhan Kepanjen, diperoleh 41 orang $(50.0 \%)$ yang terdiagnosis nyeri punggung bawah dan 41 orang $(50.0 \%)$ yang tidak terdiagnosis nyeri punggung bawah.

Nyeri Punggung Bawah adalah nyeri di daerah punggung antara sudut bawah costae (tulang rusuk) sampai lumbosacral. Nyeri juga bisa menjalar ke daerah seperti punggung bagian atas dan pangkal paha (Rachel, 2005). Adapun faktor resiko nyeri punggung bawah meliputi usia, jenis kelamin, indeks massa tubuh, merokok, pekerjaan, angkat beban yang berat berulang-ulang, membungkuk, duduk lama, dan faktor psikososial.

Overweight adalah suatu kondisi dimana perbandingan berat badan dan tinggi badan melebihi standar yang ditentukan yaitu $>25 \mathrm{~kg} / \mathrm{m} 2$. Kondisi tersebut dapat diukur dengan menggunakan metode perhitungan indeks massa tubuh. Indeks massa tubuh merupakan salah satu parameter sederhana dari pemeriksaan antropometri untuk memantau status gizi seseorang, khususnya yang berkaitan dengan kekurangan dan kelebihan berat badan. Masalah kekurangan dan kelebihan gizi pada orang dewasa merupakan masalah penting, karena selain mempunyai resiko penyakitpenyakit tertentu seperti nyeri punggung bawah, juga dapat mempengaruhi produktivitas kerja (Depkes, 2007).
Berdasarkan hasil penelitian yang telah dilakukan di RSUD Kanjuruhan Kepanjen dapat disimpulkan bahwa dari perhitungan indeks massa tubuh pada sampel yang terdiagnosis nyeri punggung bawah didapatkan hasil bahwa sebanyak 25 orang $(30.5 \%)$ memiliki IMT dengan kategori overweight dan sebanyak 16 orang (19.5\%) memiliki IMT dengan kategori normal.

Hasil pengujian dengan uji chi-square menunjukkan bahwa antara overweight dan nyeri punggung bawah di RSUD Kanjuruhan Kepanjen periode Januari-Desember 2013 mempunyai hubungan yang signifikan (bermakna) dengan nilai signifikansi $(\mathrm{p})<0.05$. Artinya overweight dapat mempengaruhi terjadinya nyeri punggung bawah. Berdasarkan hasil uji korelasi koefisien kontingensi dengan nilai $\mathrm{r}$ sebesar 0.325 menunjukkan bahwa overweight memberikan pengaruh yang tidak begitu kuat (lemah) terhadap terjadinya nyeri punggung bawah. Hal ini mungkin dikarenakan adanya faktor-faktor lain yang dapat mempengaruhi terjadinya nyeri punggung bawah, seperti aktifitas fisik, riwayat cedera/trauma, riwayat penyakit terdahulu, riwayat keluarga, merokok, posisi kerja yang tidak benar, dan factor psikologis. Berdasarkan hasil odd ratio dengan nilai OR sebesar 4.261 menunjukkan bahwa seseorang yang overweight mempunyai kemungkinan 4 kali untuk mengalami nyeri punggung bawah dibandingkan dengan seseorang yang memiliki berat badan normal. Hasil penelitian ini sesuai dengan penelitian yang dilakukan Richard dan Weinstein dalam Hendy (2010) yakni faktor risiko nyeri punggung bawah meningkat pada seseorang yang overweight. Pada penelitian Laxmaiah (2005) menyatakan adanya hubungan overweight dengan nyeri punggung bawah. Vismara L (2010) menyimpulkan bahwa peningkatan insiden nyeri punggung bawah terjadi seiring dengan peningkatan indeks massa tubuh. Pada penelitian kasus-kontrol (kasus 44 orang, kontrol 106 orang) oleh Laurence J. Fourtes (2004), didapatkan bahwa overweight $(\mathrm{OR}=2.1)$ merupakan factor resiko nyeri punggung bawah. Penelitian case control yang dilakukan oleh Setyawati di Poli Neurologi RSPAD Gatot Subroto menunjukkan bahwa ada hubungan yang bermakna antara factor risiko indeks massa tubuh dengan kejadian nyeri punggung bawah, dengan hasil OR menunjukkan bahwa IMT > $25 \mathrm{~kg} / \mathrm{m} 2$ beresiko 2,244 kali lebih besar mengalami nyeri punggung bawah dibandingkan dengan IMT $<25 \mathrm{~kg} / \mathrm{m} 2$.

Banyak faktor yang dapat memperberat terjadinya nyeri punggung bawah, salah satunya adalah indeks massa tubuh. Indeks massa tubuh mempunyai hubungan dengan keluhan nyeri punggung bawah. Hal ini didukung oleh kajian pustaka yang menyatakan bahwa orang yang memiliki indeks massa tubuh overweight $(>25 \mathrm{~kg} / \mathrm{m} 2)$ atau mengalami kegemukan memiliki lemak tubuh yang berlebih. Hal tersebut merupakan factor resiko terhadap berkembangnya keluhan nyeri punggung bawah (Eleanor Bull dan Graham Archad, 2007). Tulang belakang terutama daerah lumbal memegang peranan penting dalam menahan beban tubuh. Mereka yang memiliki proporsi tubuh normal, maka beban pada tulang belakangnya juga dalam batas normal.

Ketika seseorang kelebihan berat badan biasanya kelebihan berat badan akan disalurkan pada daerah perut 
yang berarti beban kerja tulang lumbal meningkat (Silveri, 2009). Ketika berat badan bertambah, tulang belakang akan tertekan untuk menerima beban yang membebani tersebut sehingga mengakibatkan mudahnya terjadi kerusakan dan bahaya pada struktur jaringan sekitar tulang belakang, seperti otot, tendon, ligament, dan tulang. Pada awalnya otot dan ligament yang menjaga kelengkungan tulang belakang masih dapat menjalankan fungsinya. Namun, bila hal ini terjadi terus-menerus akan terjadi kelelahan otot dan dapat mengakibatkan nyeri punggung bawah. Hal tesebut dapat berakibat aktifitas fisik seseorang menjadi terbatas. Adanya keterbatasan aktifitas seseorang yang mengalami overweight pada usia produktif akan mengganggu kinerjanya. Sejalan dengan semakin bertambahnya berat badan seseorang, akan semakin bertambah gangguan-gangguan fungsional gerak tubuh dan kerentanan akan penyakit. Salah satu daerah pada tulang belakang yang paling beresiko akibat efek dari overweight adalah vertebra lumbal.

Peneliti menyadari bahwa dalam persiapan dan pelaksanaan penelitian ini masih banyak dijumpai kekurangan dan keterbatasan. Penelitian ini mempunyai keterbatasan alat ukur untuk mengetahui factor-faktor lain yang dapat menyebabkan terjadinya nyeri punggung bawah seperti riwayat penyakit terdahulu, riwayat trauma, riwayat keluarga, beratnya aktifitas fisik,factor psikologis, dan posisi kerja yang tidak benar. Peneliti menyadari banyak kekurangan pada penelitian ini, sehingga diharapkan untuk peneliti selanjutnya dapat menyempurnakan penelitian ini pada lokasi pengamatan yang lebih luas dan sampel yang lebih banyak dan dapat memberikan hasil yang maksimal.

\section{SIMPULAN}

Berdasarkan analisis data dan hasil penelitian yang telah dilakukan, maka dapat diambil kesimpulan sebagai berikut:

1. Terdapat hubungan yang signifikan antara overweight dengan nyeri punggung bawah di RSUD Kanjuruhan Kepanjen periode JanuariDesember tahun 2013 (dengan nilai $\mathrm{p}=0.002$ ).

2. Overweight memberikan pengaruh yang tidak begitu kuat (lemah) terhadap terjadinya nyeri punggung bawah (dengan nilai $r=0.325$ ).

3. Seseorang yang overweight mempunyai resiko lebih besar untuk mengalami nyeri punggung bawah (dengan nilai $\mathrm{OR}=4.261)$.

\section{DAFTAR PUSTAKA}

Almatsier, Sunita. 2005. Prinsip Dasar Ilmu Gizi. Jakarta : Gramedia Pustaka Utama.

Bahrudin, Moch. 2013. Neurologi Klinis. Malang: UMM Press.

Bimariotejo. 2009. Low Back Pain (LBP). http:// bimariotejo.wordpress.com/2009/2007/07/07/lowback-pain-lbp/ (diakses 26 Desember 2013).

Bener et al. 2003. Obesity and Low Back Pain. Coll. Antropol, 27:95-104.

Cooper, Phyliss G. 2003. Low Back Pain. Clinical Reference System. McKesson Health Solutions LLC. Pp.1-16.
Departemen Kesehatan Republik Indonesia. 2007. Laporan Hasil Riset Kesehatan Dasar (Rikerdas). Badan Penelitian dan Pengembangan Kesehatan. Hal 48-51.

Guyton, A.C., Hall J.E., 2006. Textbook of Medical Physiology. 11th ed. Elsevier Saunders. Oxford.

Hartwig MS, Wilson LM. 2005. Nyeri. In: Huriawati Hartanto, Natalia Susi, Pita Wulansari, et al. Patofisiologi: Konsep Klinis Proses-Proses Penyakit volume II, edisi VI. Jakarta: EGC. Pp.1063-1104.

Hendy Purnamasari, dkk. 2010. Overweight sebagai Faktor Resiko Low Back Pain pada Pasien Poli Saraf Rsud Prof. Dr. Margono Soekarjo Purwokerto. Mandala of Health. Purwokerto.

Idyan, Z, 2008. Hubungan Lama Duduk Saat Perkuliahan dengan Keluhan Low Back Pain. Available from: http:/ /inna-ppni.or.id. (diakses 22 November 2013).

Judith A, Kaufmann. 2005. Low Back Pain Diagnosis and Management in Primary care. Dalam Lippincott's Primary Care Practice, Vol 3. Number 4, Philadelphia: Lippincott William \& William inc.

Knecht S, Ellegr T, Levine JA. 2008. Obesity in Neurobiology. Progress in Neurobiology ; 84:85- 103.

Lubis, I. Epidemiologi nyeri punggung bawah. Dalam : Meliala L. Suryamiharja A. Purba JS. Sadeli HA. Editors. Nyeri punggung bawah, Jakarta. Perhimpunan Dokter Spesialis Saraf Indonesia (PERDOSSI), 2003:pp.1-3.

Maher, Salmond \& Pellino. 2002. Low Back Pain Syndroma. Philadelpia: FA Davis Company.

Paliyama, J.M., 2003. Perbandingan Efek Terapi Arus Interferensi dengan TENS dalam Pengurangan Nyeri Punggung Bawah Muskuloskeletal, Fakultas Kedokteran Diponegoro, Semarang.

Rachel. Sulvana. 2005. Nyeri Punggung Bawah Pekerja Perawatan Lapangan Golf di Perusahaan X dan faktorfaktor yang berhubungan. Tesis. Jakarta: Fakultas Kedokteran Universitas Indonesia.

Richard S Snell, MD,. 2006. Anatomi Klinik untuk Mahasiswa Kedokteran Edisi 6. Jakarta : EGC.

Ropper AH, Brown RH. 2005. Adams an Victor's Principles of Neurology. 8th edn. McGraw-Hill. USA.

Rosu M. 2006. Adult Obesity Diagnosis, Etiology and Management. Pp.93-106.

Rumiyati,W. B., 2009. Perbedaan Pengaruh Intervensi Short Wave Diathermy dan back Exercise dengan Ultrasonik dan Back Exercise terhadap Penurunan Nyeri pada Nyeri Punggung Bawah Non Spesifik. Available from: http:/ / etd.eprints.ums.ac.id (Diakses 20 Agustus 2013).

Sadeli HA, Tjahjono B. 2006. Nyeri Punggung Bawah. Dalam: Nyeri Neuropatik Patofisiologi dan Penatalaksanaan. Pp. 145-167.

Sidharta, P. 2009. Neurologi Klinis Dasar. Cetakan Ke-14. Jakarta : Dian Rakyat. Hal.90-91.

Silbernagl S, Lang F. 2006. Teks \& Atlas Berwarna Patofisiologi. Jakarta: EGC.

Siswono, 2005. Pola Hidup Modern itu Potensi Obese. Available from: http://www.bwwbn.go.id/ (diakses 17 Juli 2013)

Setiyohadi B. 2007. Etiopatogenesis Nyeri Pinggang. In : Naskah Lengkap Pertemuan Ilmiah Tahunan Ilmu Penyakit Dalam. Jakarta. Agustus. pp. 162-171. 
Sugondo, Sidartawan. 2007. Buku Ajar Ilmu Penyakit Dalam jilid III edisi IV. Jakarta : FKUI. Pp.1919; 1921-1922.

Supariasa, I Dewa Nyoman. 2002. Penilaian Status Gizi. Jakarta : EGC, pp.56-62.

Soeharso. 2006. Pengantar Ilmu Bedah Orthopedi. Yogyakarta: Yayasan Essentia Medica.

Soemarmo Markam. 2011. Penuntun Neurologi. Jakarta : Binarupa Aksara. Pp.235-243.

Vismara .L., dkk. 2010. Effect of obesity and low back pain on spinal mobility: a cross sectional study in women. Available from: http://web.ebscohost.com (Diakses 20 Oktober 2013)

Wellman NS, Barbara F. 2002. Causes and Consequences of Adult Obesity: bealth, social and economic impact in the United States. Pacific J Clin Nutr. Vol 11: S705-S709.

Wheeler, A., 2009. Chronic Low Back Pain. Available from: http://emedicine.medscape.com/article (Diakses 3 Agustus 2013).

WHO (World Health Organization). 2006. BMI Classification. Report of a WHO consultation. Geneva: WHO http://apps.who.int/bmi (diakses 11 Juli 2013). 